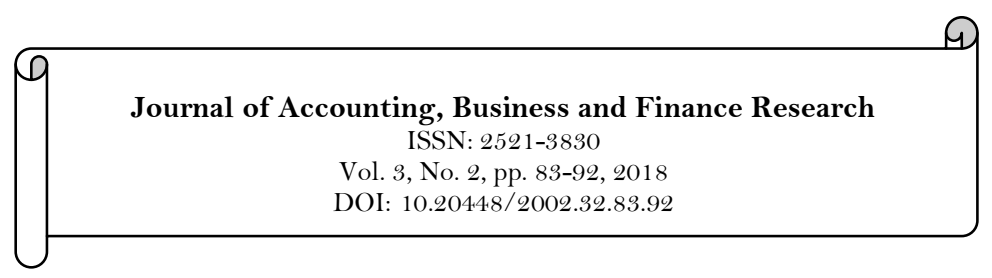

\title{
Risk and Return Analysis of Closed-End Mutual Fund in Bangladesh
}

\author{
Tasruma Sharmeen Chowdhury ${ }^{1 *}$ \\ Md.Habibullah ${ }^{2}$ \\ Nurun Nahar ${ }^{3}$ \\ ${ }^{1}$ Assistant Professor, Bangladesh Institute of Capital Market, 34, Topkhana Road, Dhaka-1000, Bangladesh. \\ ${ }^{2}$ Email: tasruma.bicmagmail.com \\ ${ }^{2}$ ACCA Affiliate, Assistant Professor, Bangladesh Institute of Capital Market, 34, Topkhana Road, Dhaka-1000, Bangladesh. \\ ${ }^{3}$ Assistant Professor, Northern University Bangladesh.
}

\begin{tabular}{|c|c|}
\hline Abstract & \\
\hline 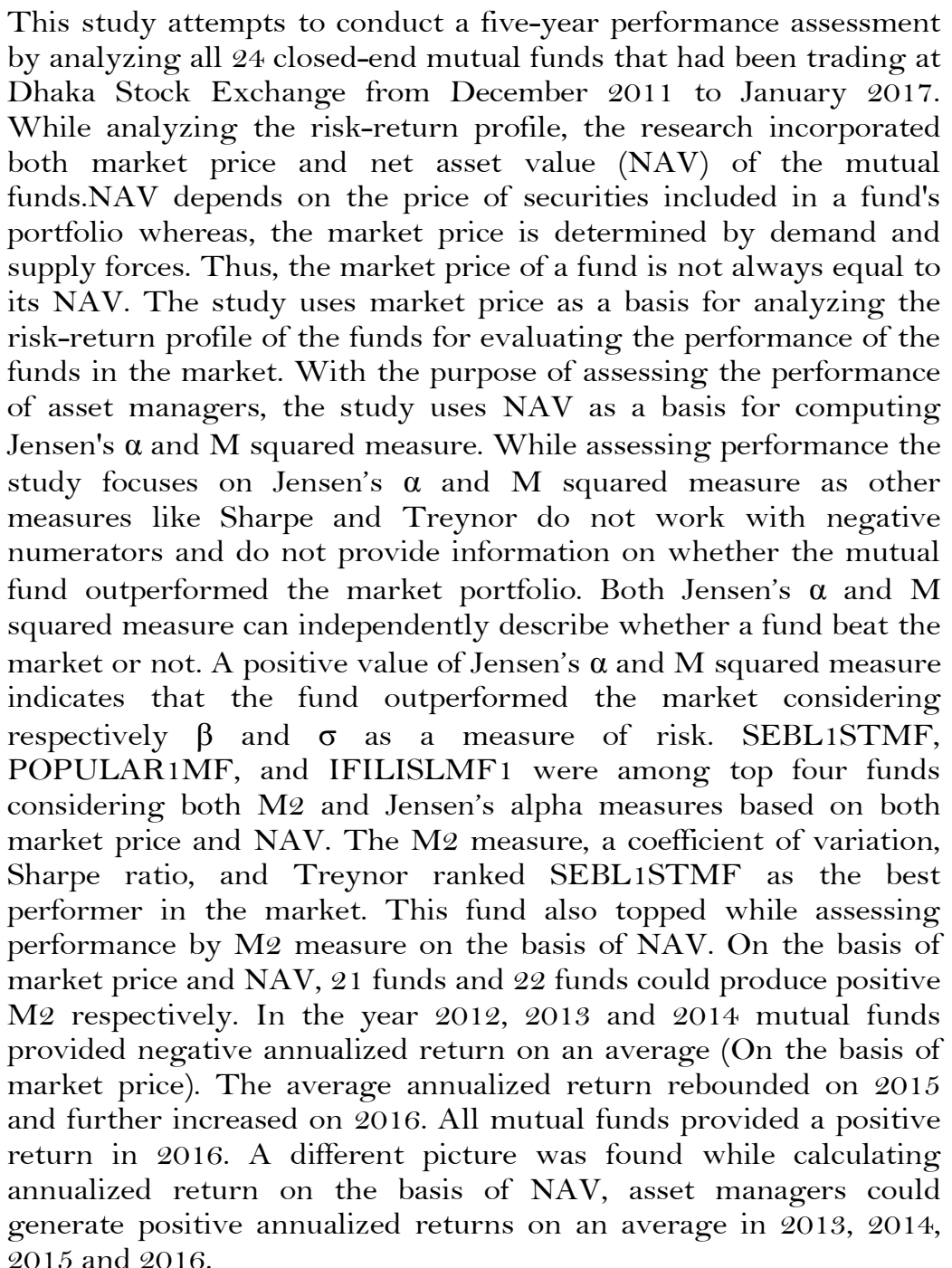 & $\begin{array}{l}\text { Keywords: } \\
\text { Mutualfund } \\
\text { DSE } \\
\text { Pefformanceanalysis } \\
\text { alpha } \\
\text { MSquare } \\
\text { Risk and retum. } \\
\text { JEL Classification: } \\
\text { G10, G11. } \\
\text { Licensed: } \\
\text { This work is licensed under a } \\
\text { Creative Commons Attribution } \\
\text { 4.0 License. } \\
\text { Publisher: } \\
\text { Scientific Publishing Institute }\end{array}$ \\
\hline
\end{tabular}




\section{Introduction}

Mutual Fund is a type of collective investment scheme (CIS) or a 'pooled investment'. It is a trust where investors put their money and a professional fund manager invests the collected fund in different types of asset, such as stocks, bond, short-term money market instruments, and other securities. It is also a way to collect small savings from the retail sector. When someone buys a share of the mutual fund it represents his/her portion of the investment portfolio. The mutual fund allows let alone investors avail the opportunity to manage their fund by the professional fund manager, which would otherwise be expensive and in most of the cases out of reach for them. It also allows them to hold a widely-diversified portfolio.

In Bangladesh, mutual funds are established and governed by Bangladesh Securities and Exchange and Commission (Mutual Fund) Rules, 2001, Trust Act, 1882 and Registration Act,1908. Although, the history of mutual fund in Bangladesh is of more than 37 years the sector is still at a nascent stage and very small in size compared to the capital market. Since the beginning of the sector in 1980, there has only been close-ended fund in the country. Investment Corporation of Bangladesh (ICB) launched the first-ever mutual fund named 'the first ICB mutual fund' that created the history of mutual fund in the country. Since then, this sector has been growing very slowly. In 2010, for the first time, an open-end mutual fund was launched in the country. There are 35 mutual funds currently trading in Dhaka Stock Exchange (DSE) by December 2016 ${ }^{1}$. The market capitalization of this sector is USD445 million which is only 1.03 percent of total market capitalization. Moreover, based on market capitalization this sector secured 12th place in December $2016^{2}$.

While the mutual fund sector has grown over time, academic studies in this sector have remained narrow. Investors are not well aware of the performance of these funds. Hence, with the development of this sector, it has become necessary to measure the performance of mutual funds in regular interval. In Bangladesh, previous studies evaluated the performance of mutual funds for a shorter period of twelve to eighteen months. In the shorter period, the performance of mutual funds can be affected by the condition of the capital market. In this context, this study considered a five-year period to incorporate both the ups and downs of the market.

The present study has been carried out to evaluate the performance of 24 close-ended mutual funds those had been trading at DSE during the period 2012 to 2016 by means of risk and return analysis using Sharpe ratio, Treynor ratio, Jensen's $\alpha$ and $M$ squared measure. The study intends to evaluate the performance of mutual funds based on both market price and net asset value (NAV). Demand and supply forces determine the market price of the closed-end mutual fund. Net asset value (NAV) represents the value of the mutual fund. NAV is calculated based on the closing price of the securities in the fund's portfolio. The market price does not always equal the NAV. Investors will get NAV per unit at the end of maturity period if he/she holds it till maturity. In order to assess the performance of the asset manager, the study uses NAV as a basis for computing Sharpe ratio, Treynor ratio, Jensen's $\alpha$, and M squared measure. The market price has been used to assess the performance of mutual funds in the market. This study uses $M$ squared measure and alpha for assessing performance as these measures can provide independent and objective results.

\section{Literature Review}

A number of researches have been done to study the performance of mutual funds. It is found that by investing in mutual funds investors can diversify their risk (Cumby \& Glen, 1990; Eun, Kolodny, \& Resnick, 1991). It is also observed that mutual funds are doing better in the domestic market than in the international market.15 US-based international mutual funds' performance has been examined and found that they did better in the domestic market than in the international market (Chen \& Jang, 1994). In an alike research, Kao, Cheng, and Chan (1998) found that international mutual fund managers are poor in making investment decisions based on economic and other factors affecting the direction of the market. Whereas, using Chines market setup, Kiymaz (2015) examined the performance of mutual funds by applying different risk-adjusted measures such as Sharpe ratio; Treynor ratio; Jensen's $\alpha$, and found that these funds outperformed market portfolio. Similarly, Noulas, Papanastasiou, and Lazaridis (2005) examined the performance of Greek equity funds considering risk and return analysis using the coefficient of variation and the systematic risk. They found a positive relationship between risk and return. They also found betas of less than one for the study period.

In a study, Qamruzzaman (2014) used risk-adjusted performance measures; Sharpe ratio, Treynor's ratio, and Jensen Alpha to find the performance of 32 growth-oriented closed-ended mutual funds on a monthly basis.In his study period market was not performing well (average return was negative) so as the mutual funds. Beta, a measure of systematic risk was found to be negative for few mutual fund schemes which resulted in dissimilar ranking of the mutual fund schemes according to the measurements.

Anwar and Hayder (2016) worked on 31 growth-oriented closed-ended mutual funds in Bangladesh and found their performance on the basis of weekly NAV and weekly close price and compared them with the market. During the study period (June 2014- June 2016) average return of the sample is higher when the calculation was based on weekly close price but lower, in fact negative, when the calculation is based on NAV

${ }^{1}$ Dhaka Stock Exchange Monthly Review December 2016. ${ }^{2}$ Dhaka Stock Exchange Monthly Review December 2016. 
than that of the market. They took worldwide accepted risk-adjusted performance measures. Positive values of each measurement indicate better performance and vice versa. Results showed consistency in the case of Jensen's measurement. They mentioned that the performance relied on both the asset management companies and the role of regulatory bodies. The authors suggested transparency in disclosing the level of risk associated with a return in the annual reports for the sake of investors and prospective investors can bring back the trust and confidence.

\subsection{Objectives of the Study}

The objectives of the study are:

- $\quad$ to find the average monthly return based on market price provided by the closed-end mutual fund to investors over 5 years

- to find the average monthly return based on NAV generated by asset managers of the closed-end mutual fund over 5 years

- to compare year-wise annualized returns based on market price and NAV

- $\quad$ to assess the performance of closed-end mutual funds in the market

- to evaluate the performance of asset managers

\section{Methodology}

This study intends to assess the performance of all Closed-end Mutual Funds that were being traded in the Dhaka Stock Exchange from December 2011 to January 2017. For five-year performance assessment, the research analyzed 24 closed-end mutual funds that were in existence during the stipulated period. Market prices of a mutual fund, as well as net asset value (NAV)s, have been considered for calculating the return. In order to evaluate the performance of the asset manager, the study uses NAV as a basis for computing Sharpe ratio, Treynor ratio, Jensen's $\alpha$ and M squared measure. The market price has been used as a basis of calculation for the assessment of the performance of the mutual fund in the market. Monthly market prices have been collected from DSE library. NAVs (based on market price) have been collected from DSE news. To determine the risk-free rate of return, the returns of 91- days Treasury Bill have been collected from the website of Bangladesh Bank. Then the annual returns have been converted to monthly returns. The broad index of Dhaka Stock Exchange, DSEX index has been considered as a benchmark. Data for DSEX index have been collected from DSE library.

This study estimates risk-return profiles for closed-end mutual funds for the five-year period. Price and NAV for 61 months (December 2011 to January 2017) have been used to compute return for 60 months (January 2012 to January 2017). Monthly returns are used for computing measures of risk as well as return.

\subsection{Return}

For analyzing price based performance, monthly returns of mutual funds are calculated using the following formula:

Where,

$$
R_{t}=\frac{\left(D_{t}+P_{t}-P_{t-1}\right)}{P_{t-1}}
$$

$R_{t}=$ Return of mutual fund in period $\mathrm{t}$

$P_{t}=$ Market price of mutual fund in period $\mathrm{t}$

$P_{t}-1=$ Market price of mutual fund in the period $t-1$

$D_{t}=$ Dividend paid by the mutual fund in period $t$

For analyzing NAV based performance, monthly returns are calculated using the following formula:

Where,

$$
R_{t}=\frac{\left(D_{t}+N A V_{t}-N A V_{t-1}\right)}{N A V_{t-1}}
$$

$R_{l}=$ Return of mutual fund in period $\mathrm{t}$

$N A V_{t}=$ Net asset value of the mutual fund in period $\mathrm{t}$

$N A V_{t}-1=$ Net asset value of the mutual fund in the period $\mathrm{t}-1$

$D_{t}=$ Dividend paid by the mutual fund in period $t$ 
These prices and NAVs are adjusted for the issuance of re-investment unit (RIU). Number of RIU per unit is calculated by the following equation:

$$
\text { No. of RIU }=\frac{\text { No. of unit holding at record date } \times \text { Face value } \times \text { Declared RIU \% }}{\text { NAV per unit market price basis }}
$$

Mean monthly returns of a mutual fund $\left(R_{i}\right)$ is found by calculating the arithmetic mean of 60 monthly returns.

Monthly market returns are calculated using the following formula:

$$
R_{t}=\frac{\text { Index }_{t}-\text { Index }_{t-1}}{\text { Index }_{t-1}}
$$

Where,

$R_{t}=$ Return in period $t$

Index $x_{t}=$ Index in period $\mathrm{t}$

Index $_{t-1}=$ Index in period $\mathrm{t}-1$

DSEX is used as a market benchmark. Average monthly market return $\left(R_{m}\right)$ is found by calculating the arithmetic mean of 60 monthly market returns.

The study uses the monthly yield of 91- days Treasury Bills over the stipulated period as a proxy of the riskfree rate of return. The average risk-free rate of return $\left(R_{f}\right)$ is found by calculating the arithmetic mean of 60 month's yields of 91- days Treasury Bills.

\subsection{Risk}

The study uses Standard deviation $\left(\sigma_{i}\right)$, Coefficient of variation $(\mathrm{CV})$ and $\operatorname{Beta}(\beta)$ for measuring risk.

$\sigma_{i \text { is }}$ used for measuring 'Total risk'. It represents the dispersion of observations from the mean. Greater $\sigma_{i \text { indicates greater deviation and higher risk. }}$

$\mathrm{CV}$ is used for measuring relative risk. It represents the risk per unit of return. The lower the value of $\mathrm{CV}$ the lower the relative risk of the fund.

This study also calculates 'Leverage Factor', which compares the risk of the fund with the risk of a market benchmark.

$L_{i}=\frac{\sigma_{m}}{\sigma_{i}}$

$\sigma_{m}=$ Standard Deviation of market returns

$\sigma_{i}=$ Standard Deviation of individual fund's return

Market risk or systematic risk is estimated by beta. Beta is calculated by using the following formula:

$\beta=\operatorname{Covarience} \frac{R_{\dot{b}} R_{m}}{\left(\sigma_{m}\right)^{2}}$

\subsection{Risk-Adjusted Performance}

Performance of individual mutual fund is assessed by Sharpe Ratio, Treynor performance measure, Jensen's Alpha, M squared measure and information ratio.

Sharpe ratio represents the risk premium earned per unit of total risk. It can be expressed as:

$$
S_{i}=\frac{R_{i}-R_{f}}{\sigma_{i}}
$$

Sharpe ratio assesses the performance on the basis of both the rate of return and total risk or variability. The fund with the higher Sharpe ratio has the better performance. But the Sharpe ratio of an individual fund by itself is not informative. The Sharpe ratio for each fund must be computed for comparing funds. Sharpe ratio with negative numerator provides an incorrect ranking. It is another limitation of the Sharpe ratio.

Treynor performance measure considers market risk or systematic risk. It assumes portfolio of a mutual fund should be completely diversified. Thus, the pertinent risk for achieving higher return compensations should be the market risk which is not diversifiable. Treynor performance measure can be expressed as: 


$$
T_{i}=\frac{R_{i}-R_{f}}{\beta_{i}}
$$

This represents the risk premium return per unit of systematic risk. The greater value of Treynor measure is preferable to investors. Treynor ratio does not work for negative numerators. It also requires positive beta to provide a meaningful ranking.

Both Sharpe and Treynor ratios do not provide information on whether the mutual fund outperformed the market portfolio. They do not provide information about the degree of superiority of a higher ratio of mutual fund over a lower ratio mutual fund.

As both the Sharpe ratio and Treynor ratio have some limitations, this study uses other measures for ranking purpose. While considering the total risk M Squared $\left(M^{2}\right)$ measure is used and based on market risk Jensen Measure is used for ranking the mutual funds' performance.

M Squared $\left(M^{2}\right)$ measure is an alternative way of raking the performance of mutual funds. It can be expressed as:

$$
M^{2}=\left(R_{i}-R_{f}\right) \times\left(\frac{\sigma_{m}}{\sigma_{i}}\right)-\left(R_{m}-R_{f}\right)
$$

$M^{2}$ value equal to zero indicates that the performance of the mutual fund matches that of the market. A positive value of $M^{2}$ indicates that, the mutual fund beats the market on a risk-adjusted basis.

Jensen's alpha is based on market risk. Jensen's Alpha represents the difference of actual mean return and the expected return of each mutual fund. It can be expressed as:

$$
\text { Jensen's alpha }=\alpha_{i}=R_{i}-\left[R_{f}+\beta_{i}\left(R_{m}-R_{f}\right)\right]
$$

A positive value of Jensen's alpha means the mutual fund outperformed the market. On the other hand, a negative value indicates underperformance in comparison with the market.

\section{Results}

\subsection{Analysis Based on Market Price of Mutual Funds}

Mean monthly return based on the market price of 24 mutual funds along with their total risk, relative risk, systematic risk, risk-adjusted performance measures is presented in Appendix Table 1.

\subsection{Return (Based on Market Price)}

The highest average monthly return (Based on market price) over a five-year period (2012-2016) was $3.00 \%$ earned by POPULAR1MF, and its closest competitor was IFILISLMF $1(2.10 \%)$ when market produced $0.77 \%$ (DSEX index) average monthly return. The least average monthly return, $0.64 \%$ earned by EBLNRBMF. LRGLOBMF 1 earned $0.76 \%$ average monthly return. These two funds provided a negative market adjusted return ( $\mathrm{Ri}-\mathrm{Rm})$. However, all of the funds showed positive average monthly returns. All funds except two produced a positive market adjusted return which indicated investing in mutual funds is becoming attractive.

Year-wise annualized return on the funds is presented in Appendix Table 2. An annualized return has been calculated by compounding return relatives for 12 months. On an average return of funds in the year 2012, 2013 and 2014 were negative. Return turned green in 2015 and increased in 2016.

\subsection{Risk (Based on Market Price)}

1STPRIMFMF showed the highest total risk $\sigma(22.28 \%$, return $=1.82 \%)$, the measure of total risk, and SEBL1STMF showed the least risk $(5.91 \%$, return $=1.83 \%)$ while the standard deviation of the DSEX index was $5.62 \%$. Though total risk varied highly for the two MFs, average monthly returns were almost similar for them which indicated that investment on most risky fund yield as same as an investment on the least risky fund. All of the closed end mutual funds showed total risk lower than that of the market. The fund with the lowest relative risk (3.23) was SEBL1STMF. That means SEBL1STMF bore the lowest risk per unit of return. The highest relative risk (CV) was borne by EBLNRBMF (16.66).

Table 1 also presents the values of fund Betas. 20 out of 24 funds had beta value lower than 1 . Those which had betas higher than 1 were POPULAR1MF, GRAMEENS2, IFIC1STMF, and PF1STMF. These funds were more sensitive to market movement. The market beta was 1 . The fund with the highest beta was POPULAR1MF (1.13). That means the fund was theoretically $13 \%$ more volatile than the market. SEBL1STMF showed the lowest beta (0.29). It indicates that the fund's excess return was expected to outperform by $71 \%$ during bearish markets and underperform the benchmark by $71 \%$ in bullish markets.

The leverage factor of all funds was below 1, which implies that the total risk of the fund is greater than that of the market index. Investors should not use the borrowed fund to purchase funds having leverage factor less than 1. 


\subsection{Performance (Based on Market Price)}

SEBL1STMF achieved the highest Sharpe measure of 0.2105 , which implies that the fund generated 0.2105 units of excess return per unit of total risk. In comparison, the Sharpe measure of the DSEX index was 0.03393.SEBL1STMF also had highest Treynor measure (0.0434) and for DSE index it was 0.0019. SEBL1STMF obtained the highest $\mathrm{M}^{2}$ (0.0099). Appendix Table 1 shows 21 funds produced positive $\mathrm{M}^{2}$, that means, 21 funds outperformed market considering $\sigma$ as a measure of risk. POPULAR1MF produced the highest Alpha, 0.0220 or $2.20 \%$, which represents the fund generated a return of 2.20 percent per period more than that was expected given the portfolio's risk level. Appendix Table 1 presents, all funds except one (EBLNRBMF) generated positive alpha. That means, 23 funds outperformed the market.

Appendix Table 3 represents a ranking of funds based on $\mathrm{M}^{2}$ and Jensen's alpha. SEBL1STMF, POPULAR1MF, ICB1STNRB, and IFILISLMF1 were among top five funds considering both $\mathrm{M}^{2}$ and Jensen's alpha measures.

\subsection{Analysis Based on NAV of Mutual Funds}

Mean monthly return based on NAV of 24 mutual funds and their total risk, relative risk, systematic risk, risk-adjusted performance measures are presented in Appendix Table 4.

\subsection{Return (Based on NAV)}

ICBEPMF $1 \mathrm{~S} 1$ produced the highest average monthly return (Based on NAV), $1.53 \%$, over a five-year period (2012-2016) and POPULAR1MF produced the second largest average monthly return, $1.51 \%$. DBH1STMF was the least attractive fund (0.61\%) to invest considering return only. The year-wise annualized return (based on NAV) of funds is presented in Appendix Table 5. Average annualized return of all mutual funds in year 2012,2013,2014,2015 and 2016 were -5.0784, 11.8044, 13.5473, 8.6336 and 16.1777 respectively. In the year 2012, 15 mutual funds had a negative return (based on NAV). All except one mutual fund generated a positive return (based on NAV) in the year 2015. Annual returns of all mutual fund were positive in 2013, 2014 and 2016.

\subsection{Risk (Based on NAV)}

The three least risky funds were LRGLOBMF1 (2.51\%), SEBL1STMF (2.53\%) and RELIANCE1 (2.90\%) and the three most risky funds were 1STPRIMFMF (7.51\%), ICBEPMF1S1 (6.53\%) and ICB1STNRB $(6.36 \%)$ considering total risk. SEBL1STMF carried the lowest relative risk. Only one fund, 1STPRIMFMF had a beta greater than 1 and SEBL1STMF had the lowest beta value, 0.18.

\subsection{Performance (Based on NAV)}

SEBL1STMF obtained the highest Sharpe measure (0.2571, the portfolio manager generated 0.2571 units of excess return per unit of total risk). SEBL1STMF had the highest Treynor measure (0.0368) also. The fund with the highest $\mathrm{M}^{2}(0.0125)$ was also SEBL1STMF. Treynor ratio and Sharpe ratio provided an identical ranking for the fund, which can be interpreted as that this fund is theoretically completely diversified. Table 6 shows, 22 funds had positive $\mathrm{M}^{2}$ that means 22 funds beat market. POPULAR1MF had the highest Alpha value (0.0085). Table 1 presents, all funds except 2 generated positive Alpha. That indicates based on NAV, 22 funds could realize an abnormal return. These 22 funds outperformed the market and generated return more than what would have been expected given the risk level of the funds.

Appendix Table 6 represents a ranking of funds based on $\mathrm{M}^{2}$ and Jensen's alpha. SEBL1STMF, POPULAR1MF, IFILISLMF1, and ICB2NDNRB were among top seven funds considering both $\mathrm{M}^{2}$ and Jensen's alpha measures.

\section{Conclusion}

The study assessed the performance of mutual funds based on both market price and net asset value (NAV). The market price has been used as a basis of calculation for evaluating the performance of the mutual fund in the market. In order to assess the performance of asset manager, the study uses NAV as a basis for computing Sharpe ratio, Treynor ratio, Jensen's $\alpha$, and M squared measure. The highest average monthly return (based on market price) over a five-year period was $3.00 \%$ earned by POPULAR $1 \mathrm{MF}$ (3.00\%). In the year 2012, 2013 and 2014 mutual funds demonstrated a negative annualized return on an average (on the basis of market price). The average annualized return became positive in 2015 and further increased in 2016. All mutual funds provided a positive return on 2016. On the basis of NAV on average mutual funds provided positive annualized returns in 2013, 2014, 2015 and 2016. The five-year analysis shows SEBL1STMF had the highest Sharpe ratio, Treynor ratio, and $\mathrm{M}^{2}$. It also carried the lowest $\mathrm{CV}$. This fund also topped while assessing performance on the basis of NAV. SEBL1STMF, POPULAR1MF, and IFILISLMF 1 were among top four funds considering both $\mathrm{M}^{2}$ and Jensen's alpha measures based on both market price and NAV. On the basis of market price, 21 funds demonstrated positive $\mathrm{M}^{2}$ whereas 23 funds produced positive alpha. On the other hand,on the basis of NAV 22 fund could produce positive $\mathrm{M}^{2}$ as well as alpha. However, while evaluating the performance of Mutual Funds, this study does not address the management techniques and strategies 
followed by asset managers. In the future, research can be conducted evaluating the strategies followed by asset managers.

\section{References}

Anwar, S. R., \& Hayder, A. T. M. (2016). Evaluation of mutual funds performance in Bangladesh: Investors and market perspective. Global Journal of Management and Business Research, 16(9), 1 - 10.

Chen, S.-N., \& Jang, H. (1994). On selectivity and market timing ability of U.S.-based international mutual funds: Using refined Jensen's measure. Global Finance Journal, 5(1), 1-15.

Cumby, R. E., \& Glen, J. D. (1990). Evaluating the performance of international mutual funds. Journal of Finance, 45(2), 497-521. Available at: 10.1111/j.1540-6261.1990.tb03700.x.

Eun, C. S., Kolodny, R., \& Resnick, B. G. (1991). U.S.-based international mutual funds: A performance evaluation. Journal of Portfolio Mangement, 17(3), 88-94. Available at: 10.3905/jpm.1991.409337.

Kao, G. W., Cheng, L. T., \& Chan, K. C. (1998). International mutual fund selectivity and market timing during up and down market conditions. Financial Review, 33(2), 127-144. Available at: 10.1111/j.1540-6288.1998.tbo1373.x.

Kiymaz, H. (2015). A performance evaluation of Chinese mutual funds. International Journal of Emerging Markets, 10(4), 820-836. Available at: 10.1108/IJoEM-09-2014-0136.

Noulas, A. G., Papanastasiou, J. A., \& Lazaridis, J. (2005). Performance of mutual funds. Managerial Finance, $31(2), 101-112$. Available at: http://dx.doi.org/10.1108/03074350510769523.

Qamruzzaman, A. M. (2014). Comparative study on performance evaluation of mutual fund schemes in Bangladesh: An analysis of monthly returns. Journal of Business Studies Quarterly, 5(4), 190-209.

\section{Appendix}

Table-1. Five-year performance (Based on market price) of closed -end mutual funds of DSE on a monthly basis using DSEX index as benchmark (Feb 2012- Jan 2017).

\begin{tabular}{|c|c|c|c|c|c|c|c|c|c|}
\hline & $\begin{array}{l}\text { Average } \\
\text { monthly } \\
\text { return } \\
(\%)\end{array}$ & $\sigma(\%)$ & CV & $\beta$ & $\begin{array}{l}\text { Sharpe } \\
\text { ratio }\end{array}$ & $\begin{array}{l}\text { Treynor } \\
\text { ratio }\end{array}$ & $\alpha$ & $\mathbf{L}_{\mathrm{i}}$ & $\mathbf{M}^{2}$ \\
\hline 1JANATAMF & 0.84 & 9.77 & 11.59 & 0.82 & 0.0265 & 0.0032 & 0.0010 & 0.5749 & -0.0004 \\
\hline 1STPRIMFMF & 1.82 & 22.28 & 12.24 & 0.55 & 0.0555 & 0.0225 & 0.0113 & 0.2520 & 0.0012 \\
\hline AIBL1STIMF & 1.39 & 12.46 & 8.95 & 0.66 & 0.0648 & 0.0122 & 0.0068 & 0.4507 & 0.0017 \\
\hline DBH1STMF & 1.17 & 11.91 & 10.14 & 0.80 & 0.0496 & 0.0074 & 0.0044 & 0.4717 & 0.0009 \\
\hline EBL1STMF & 1.01 & 9.10 & 9.01 & 0.85 & 0.0469 & 0.0050 & 0.0026 & 0.6172 & 0.0007 \\
\hline EBLNRBMF & 0.64 & 10.63 & 16.66 & 0.71 & 0.0051 & 0.0008 & -0.0008 & 0.5282 & -0.0016 \\
\hline GRAMEENS2 & 1.37 & 12.85 & 9.37 & 1.09 & 0.0612 & 0.0072 & 0.0058 & 0.4370 & 0.0015 \\
\hline GREENDELMF & 1.59 & 13.13 & 8.27 & 0.80 & 0.0765 & 0.0125 & 0.0085 & 0.4276 & 0.0024 \\
\hline ICB1STNRB & 1.83 & 9.32 & 5.08 & 0.54 & 0.1343 & 0.0230 & 0.0115 & 0.6028 & 0.0056 \\
\hline ICB2NDNRB & 1.63 & 10.68 & 6.54 & 0.86 & 0.0982 & 0.0121 & 0.0088 & 0.5257 & 0.0036 \\
\hline ICB3RDNRB & 1.56 & 11.75 & 7.55 & 0.73 & 0.0828 & 0.0133 & 0.0083 & 0.4778 & 0.0027 \\
\hline ICBAMCL2ND & 1.74 & 11.82 & 6.78 & 0.85 & 0.0982 & 0.0136 & 0.0100 & 0.4750 & 0.0036 \\
\hline ICBEPMF 1S 1 & 1.68 & 12.31 & 7.34 & 0.77 & 0.0888 & 0.0143 & 0.0095 & 0.4560 & 0.0031 \\
\hline IFIC1STMF & 1.38 & 10.58 & 7.68 & 1.06 & 0.0751 & 0.0075 & 0.0059 & 0.5307 & 0.0023 \\
\hline IFILISLMF 1 & 2.10 & 12.13 & 5.77 & 0.89 & 0.1253 & 0.0171 & 0.0135 & 0.4629 & 0.0051 \\
\hline LRGLOBMF 1 & 0.76 & 10.07 & 13.34 & 0.57 & 0.0170 & 0.0030 & 0.0006 & 0.5574 & -0.0009 \\
\hline MBL1STMF & 1.04 & 11.08 & 10.68 & 0.97 & 0.0410 & 0.0047 & 0.0027 & 0.5070 & 0.0004 \\
\hline PF1STMF & 1.93 & 14.64 & 7.59 & 1.01 & 0.0918 & 0.0133 & 0.0115 & 0.3837 & 0.0033 \\
\hline PHPMF 1 & 1.22 & 12.64 & 10.32 & 0.95 & 0.0507 & 0.0067 & 0.0046 & 0.4443 & 0.0009 \\
\hline POPULAR1MF & 3.00 & 17.89 & 5.96 & 1.13 & 0.1352 & 0.0214 & 0.0220 & 0.3140 & 0.0057 \\
\hline PRIME1ICBA & 1.35 & 12.70 & 9.43 & 0.79 & 0.0601 & 0.0097 & 0.0061 & 0.4421 & 0.0015 \\
\hline RELIANCE 1 & 1.25 & 8.64 & 6.89 & 0.72 & 0.0776 & 0.0093 & 0.0053 & 0.6502 & 0.0025 \\
\hline SEBL1STMF & 1.83 & 5.91 & 3.23 & 0.29 & 0.2105 & 0.0434 & 0.0119 & 0.9496 & 0.0099 \\
\hline TRUSTB1MF & 0.99 & 10.80 & 10.86 & 0.89 & 0.0380 & 0.0046 & 0.0024 & 0.5199 & 0.0002 \\
\hline DSEX & 0.77 & 5.62 & 7.25 & 1.00 & 0.0339 & 0.0019 & 0.0000 & 1.0000 & 0.0000 \\
\hline 91 days Treasury Bill & 0.58 & 0.23 & 2.59 & 0.00 & 0.0000 & 0.0000 & 0.0000 & 24.9553 & -0.0019 \\
\hline
\end{tabular}


Table-2. Year-wise annualized return (Based on market price) of closed -end mutual funds of DSE.

\begin{tabular}{l|l|l|l|l|l}
\hline Annualized returns (\%) & $\mathbf{2 0 1 2}$ & $\mathbf{2 0 1 3}$ & $\mathbf{2 0 1 4}$ & $\mathbf{2 0 1 5}$ & $\mathbf{2 0 1 6}$ \\
\hline 1JANATAMF & -21.3483 & -14.2857 & -4.9105 & -7.2212 & 43.6581 \\
1STPRIMFMF & 51.5648 & -6.1427 & -32.2680 & -31.1617 & 26.3830 \\
AIBL1STIMF & -11.9048 & -2.7027 & -32.4449 & 62.2222 & 34.5167 \\
DBH1STMF & -14.4578 & -21.1268 & -16.8085 & 15.7845 & 59.4711 \\
EBL1STMF & -2.3392 & -14.1438 & -7.3571 & -15.5721 & 60.3938 \\
EBLNRBMF & -10.4762 & -9.9764 & -31.4188 & -11.9509 & 76.2024 \\
GRAMEENS2 & 26.7930 & -10.3945 & -25.4275 & -5.9230 & 45.8439 \\
GREENDELMF & 1.4706 & -23.1884 & -13.2075 & 12.3913 & 66.2571 \\
ICB1STNRB & 5.0845 & 5.7173 & -5.5889 & 17.0936 & 33.8099 \\
ICB2NDNRB & 9.8416 & -14.5991 & -6.9232 & 27.8193 & 23.8027 \\
ICB3RDNRB & -10.3896 & -26.0870 & -4.7659 & 17.9996 & 59.2795 \\
ICBAMCL2ND & -10.0931 & -20.5479 & -10.8504 & 18.1564 & 57.7210 \\
ICBEPMF1S50 & 2.9476 & -29.6296 & -10.8273 & 62.7912 & 27.0348 \\
IFIC1STMF & 12.3604 & -10.2895 & -14.8145 & -8.0992 & 29.5141 \\
IFILISLMF1 & -1.5873 & -9.6774 & 21.3599 & 27.5304 & 28.1366 \\
LRGLOBMF1 & -2.0816 & -24.3063 & -24.0619 & 30.0000 & 38.1818 \\
MBL1STMF & -25.0000 & -8.6957 & -25.9897 & 26.6667 & 46.3659 \\
PF1STMF & 8.5135 & -26.0274 & -5.3498 & 1.2287 & 57.7381 \\
PHPMF1 & -1.4706 & -17.9104 & -6.5384 & -7.0260 & 31.7073 \\
POPULAR1MF & 4.3478 & -14.7000 & -7.9500 & -7.5580 & 140.3727 \\
PRIME1ICBA & -13.6374 & -21.4286 & -11.1111 & 15.2174 & 43.7710 \\
RELIANCE1 & -9.6095 & 5.5748 & -4.1616 & 11.1111 & 57.7236 \\
SEBL1STMF & 6.6102 & 1.9100 & 18.3812 & 30.6250 & 48.5709 \\
TRUSTB1MF & 4.2141 & -10.0166 & -18.2950 & -12.9289 & 42.4182 \\
DSEX & -19.7484 & 11.4219 & 14.0257 & -4.8371 & 8.7784 \\
Average of 24 Closed-end mutual funds & -0.0270 & -13.4448 & -11.7221 & 11.2165 & 49.1198 \\
\hline
\end{tabular}

Table-3. Five-year ranking (Based on market price) of closed -end mutual funds of DSE on a monthly basis using DSEX index as benchmark (Feb 2012- Jan 2017).

\begin{tabular}{l|l|l}
\hline Name of Mutual Fund & Ranking based on $\mathbf{M}^{2}$ & Ranking based on Jensen's alpha \\
\hline SEBL1STMF & 1 & 3 \\
\hline POPULAR1MF & 2 & 1 \\
\hline ICB1STNRB & 3 & 5 \\
\hline IFILISLMF1 & 4 & 2 \\
\hline ICBAMCL2ND & 5 & 7 \\
\hline ICB2NDNRB & 6 & 9 \\
\hline PF1STMF & 7 & 4 \\
\hline ICBEPMF1S1 & 8 & 8 \\
\hline ICB3RDNRB & 9 & 11 \\
\hline RELIANCE1 & 10 & 16 \\
\hline GREENDELMF & 11 & 10 \\
\hline IFIC1STMF & 12 & 14 \\
\hline AIBL1STIMF & 13 & 12 \\
\hline GRAMEENS2 & 15 \\
\hline PRIME1ICBA & 14 & 13 \\
\hline 1STPRIMFMF & 15 & 6 \\
\hline PHPMF1 & 16 & 17 \\
\hline DBH1STMF & 17 & 18 \\
\hline EBL1STMF & 18 & 20 \\
\hline MBL1STMF & 19 & 19 \\
\hline TRUSTB1MF & 20 & 21 \\
\hline 1JANATAMF & 21 & 22 \\
\hline LRGLOBMF1 & 22 & 23 \\
\hline EBLNRBMF & 23 & 24 \\
\hline & 24 & \\
\hline
\end{tabular}


Table-4. Five-year performance (Based on NAV) of closed -end mutual funds of DSE on a monthly basis using DSEX index as benchmark (Feb 2012- Jan 2017).

\begin{tabular}{|c|c|c|c|c|c|c|c|c|c|}
\hline & $\begin{array}{l}\text { Average } \\
\text { monthly } \\
\text { return } \\
(\%)\end{array}$ & $\boldsymbol{\sigma}$ & CV & $\beta$ & $\begin{array}{l}\text { Sharpe } \\
\text { ratio }\end{array}$ & $\begin{array}{l}\text { Treynor } \\
\text { ratio }\end{array}$ & $\alpha$ & $\mathbf{L}_{i}$ & $\mathbf{M}^{2}$ \\
\hline 1JANATAMF & 1.20 & 3.26 & 2.72 & 0.46 & 0.1892 & 0.0134 & 0.0053 & 1.7204 & 0.0087 \\
\hline 1STPRIMFMF & 1.04 & 7.51 & 7.25 & 1.06 & 0.0602 & 0.0043 & 0.0025 & 0.7479 & 0.0015 \\
\hline AIBL1STIMF & 0.77 & 3.15 & 4.10 & 0.33 & 0.0584 & 0.0056 & 0.0012 & 1.7854 & 0.0014 \\
\hline DBH1STMF & 0.61 & 3.67 & 6.02 & 0.45 & 0.0069 & 0.0006 & -0.0006 & 1.5307 & -0.0015 \\
\hline EBL1STMF & 1.06 & 4.28 & 4.03 & 0.58 & 0.1116 & 0.0082 & 0.0037 & 1.3110 & 0.0044 \\
\hline EBLNRBMF & 0.80 & 3.51 & 4.40 & 0.39 & 0.0613 & 0.0056 & 0.0014 & 1.5978 & 0.0015 \\
\hline GRAMEENS 2 & 1.19 & 3.88 & 3.25 & 0.45 & 0.1575 & 0.0136 & 0.0052 & 1.4489 & 0.0069 \\
\hline GREENDELMF & 0.70 & 2.93 & 4.21 & 0.36 & 0.0385 & 0.0031 & 0.0004 & 1.9137 & 0.0003 \\
\hline ICB1STNRB & 1.37 & 6.36 & 4.64 & 0.96 & 0.1239 & 0.0082 & 0.0061 & 0.8828 & 0.0051 \\
\hline ICB 2 NDNRB & 1.47 & 6.07 & 4.14 & 0.92 & 0.1456 & 0.0096 & 0.0071 & 0.9257 & 0.0063 \\
\hline ICB3RDNRB & 1.42 & 6.20 & 4.36 & 0.93 & 0.1353 & 0.0091 & 0.0066 & 0.9056 & 0.0057 \\
\hline ICBAMCL2ND & 1.39 & 6.26 & 4.51 & 0.96 & 0.1285 & 0.0084 & 0.0062 & 0.8969 & 0.0053 \\
\hline ICBEPMF 1S 1 & 1.53 & 6.53 & 4.26 & 0.98 & 0.1451 & 0.0096 & 0.0076 & 0.8604 & 0.0062 \\
\hline IFIC1STMF & 1.00 & 3.61 & 3.60 & 0.46 & 0.1161 & 0.0091 & 0.0033 & 1.5546 & 0.0046 \\
\hline IFILISLMF 1 & 1.38 & 5.02 & 3.62 & 0.68 & 0.1596 & 0.0117 & 0.0067 & 1.1193 & 0.0071 \\
\hline LRGLOBMF $1_{1}$ & 0.64 & 2.51 & 3.93 & 0.32 & 0.0219 & 0.0017 & -0.0001 & 2.2344 & -0.0007 \\
\hline MBL1STMF & 0.74 & 3.75 & 5.05 & 0.39 & 0.0426 & 0.0041 & 0.0009 & 1.4969 & 0.0005 \\
\hline PF1STMF & 1.21 & 6.05 & 5.00 & 0.93 & 0.1033 & 0.0067 & 0.0045 & 0.9287 & 0.0039 \\
\hline PHPMF 1 & 0.90 & 3.55 & 3.93 & 0.42 & 0.0901 & 0.0075 & 0.0024 & 1.5798 & 0.0032 \\
\hline POPULAR1MF & 1.51 & 5.86 & 3.88 & 0.39 & 0.1579 & 0.0237 & 0.0085 & 0.9586 & 0.0070 \\
\hline PRIME1ICBA & 1.19 & 5.83 & 4.88 & 0.91 & 0.1046 & 0.0067 & 0.0044 & 0.9634 & 0.0040 \\
\hline RELIANCE1 & 1.17 & 2.90 & 2.48 & 0.31 & 0.2022 & 0.0190 & 0.0053 & 1.9361 & 0.0094 \\
\hline SEBL1STMF & 1.24 & 2.53 & 2.05 & 0.18 & 0.2571 & 0.0368 & 0.0062 & 2.2169 & 0.0125 \\
\hline TRUSTB1MF & 0.93 & 3.84 & 4.11 & 0.50 & 0.0911 & 0.0070 & 0.0025 & 1.4643 & 0.0032 \\
\hline DSEX & 0.77 & 5.62 & 7.25 & 1.00 & 0.0339 & 0.0019 & 0.0000 & 1.0000 & 0.0000 \\
\hline $\begin{array}{l}91 \text { days } \text { Treasury } \\
\text { Bill }\end{array}$ & 0.58 & 0.23 & 0.39 & 0.00 & 0.0000 & 0.0000 & 0.0000 & 24.9553 & -0.0019 \\
\hline
\end{tabular}

Table 4: Five-year performance (Based on NAV) of closed -end mutual funds of DSE on a monthly basis using DSEX index as benchmark (Feb 2012- Jan 2017)

Table-5.Year-wise annualized return (Based on NAV) of closed -end mutual funds of DSE.

\begin{tabular}{|c|c|c|c|c|c|}
\hline \multicolumn{6}{|l|}{ Annualized returns (\%) } \\
\hline & 2012 & 2013 & 2014 & 2015 & 2016 \\
\hline 1JANATAMF & 1.3605 & 10.8501 & 19.2076 & 12.1241 & 6.7434 \\
\hline 1STPRIMFMF & -17.1082 & 10.5234 & 9.4640 & -1.7644 & 19.2063 \\
\hline AIBL1STIMF & 0.3195 & 6.4756 & 5.7717 & 17.5124 & 4.0155 \\
\hline DBH1STMF & -4.0752 & 7.4074 & 2.2380 & 11.6619 & 1.3041 \\
\hline EBL1STMF & 2.0944 & 0.6287 & 18.6071 & 11.4929 & 26.1434 \\
\hline EBLNRBMF & 1.2488 & 6.0196 & 9.8059 & 6.3468 & 42.3294 \\
\hline GRAMEENS2 & -0.4050 & 22.5239 & 16.5555 & 2.5409 & 23.5011 \\
\hline GREENDELMF & -1.0078 & 6.6742 & 7.2110 & 7.9045 & 5.2755 \\
\hline ICB1STNRB & -14.5570 & 13.8443 & 13.8410 & 8.2909 & 24.7929 \\
\hline ICB2NDNRB & -14.0197 & 15.6142 & 13.3787 & 14.0362 & 22.6911 \\
\hline ICB3RDNRB & -15.6499 & 15.0943 & 15.5227 & 12.2934 & 20.9518 \\
\hline ICBAMCL2ND & -17.2797 & 13.9276 & 15.5948 & 11.1589 & 22.2416 \\
\hline ICBEPMF 1S50 & -16.2726 & 14.7920 & 20.1711 & 10.5218 & 23.9541 \\
\hline IFIC1STMF & 6.8331 & 4.7316 & 13.3191 & 7.4914 & 8.5252 \\
\hline IFILISLMF 1 & -9.2308 & 26.8362 & 20.3592 & 4.8631 & 14.9961 \\
\hline LRGLOBMF 1 & 0.2343 & 10.4842 & 2.6859 & 8.8889 & 5.3554 \\
\hline MBL1STMF & 0.1081 & 6.9114 & 4.2736 & 13.5458 & 3.8920 \\
\hline PF1STMF & -16.0545 & 12.7962 & 19.1663 & 3.6564 & 13.4323 \\
\hline PHPMF 1 & -1.3378 & 9.1525 & 15.5971 & 9.8160 & 0.9506 \\
\hline POPULAR1MF & 1.1518 & 9.0357 & 16.1494 & 9.2363 & 38.4757 \\
\hline PRIME1ICBA & -16.4388 & 14.5706 & 20.2877 & 4.3372 & 12.8626 \\
\hline RELIANCE 1 & -0.1648 & 26.9326 & 12.5535 & 2.8891 & 17.8009 \\
\hline SEBL1STMF & 9.4435 & 11.2351 & 20.4005 & 10.2965 & 20.1121 \\
\hline TRUSTB1MF & -1.0736 & 6.2447 & 12.9748 & 8.0652 & 8.7108 \\
\hline DSEX & -19.7484 & 11.4219 & 14.0257 & -4.8371 & 8.7784 \\
\hline Average of 24 Closed-end mutual funds & -5.0784 & 11.8044 & 13.5473 & 8.6336 & 16.1777 \\
\hline
\end{tabular}


Table-6. Five-year ranking (Based on NAV) of closed -end mutual funds of DSE on a monthly basis using DSEX index as benchmark (Feb 2012- Jan 2017).

\begin{tabular}{l|l|l}
\hline & Ranking based on $\mathbf{M}^{\mathbf{2}}$ & Ranking based on Jensen's alpha \\
\hline SEBL1STMF & 1 & 7 \\
\hline RELIANCE1 & 2 & 10 \\
\hline 1JANATAMF & 3 & 9 \\
\hline IFILISLMF1 & 4 & 4 \\
\hline POPULAR1MF & 5 & 1 \\
\hline GRAMEENS2 & 6 & 11 \\
\hline ICB2NDNRB & 7 & 3 \\
\hline ICBEPMF1S1 & 8 & 2 \\
\hline ICB3RDNRB & 9 & 5 \\
\hline ICBAMCL2ND & 10 & 6 \\
\hline ICB1STNRB & 11 & 8 \\
\hline IFIC1STMF & 12 & 15 \\
\hline EBL1STMF & 13 & 14 \\
\hline PRIME1ICBA & 14 & 13 \\
\hline PF1STMF & 15 & 12 \\
\hline TRUSTB1MF & 16 & 16 \\
\hline PHPMF1 & 17 & 18 \\
\hline EBLNRBMF & 18 & 19 \\
\hline 1STPRIMFMF & 19 & 17 \\
\hline AIBL1STIMF & 20 & 20 \\
\hline MBL1STMF & 21 & 21 \\
\hline GREENDELMF & 22 & 22 \\
\hline LRGLOBMF1 & 23 & 23 \\
\hline DBH1STMF & 24 & 24 \\
\hline & &
\end{tabular}

Table-7. Name of Mutual Funds.

\begin{tabular}{l|l}
\hline & Name of the fund \\
\hline 1JANATAMF & First Janata Bank Mutual Fund \\
\hline 1STPRIMFMF & Prime Finance First Mutual Fund \\
\hline AIBL1STIMF & AIBL 1st Islamic Mutual Fund \\
\hline DBH1STMF & DBH First Mutual Fund \\
\hline EBL1STMF & EBL First Mutual Fund \\
\hline GBLNRBMF & EBL NRB Mutual Fund \\
\hline GREENDELMF & Grameen One : Scheme Two \\
\hline ICB1STNRB & Green Delta Mutual Fund \\
\hline ICB2NDNRB & ICB AMCL 1st NRB Mutual Fund \\
\hline ICB3RDNRB & ICB AMCL 2nd NRB Mutual Fund \\
\hline ICBAMCL2ND & ICB AMCL Third NRB Mutual Fund \\
\hline ICBEPMF1S1 & ICB AMCL Second Mutual Fund \\
\hline IFIC1STMF & ICB Employees Provident MF 1: Scheme 1 \\
\hline IFILISLMF1 & IFIC Bank 1st Mutual Fund \\
\hline LRGLOBMF1 & IFIL Islamic Mutual Fund-1 \\
\hline MBL1STMF & LR Global Bangladesh Mutual Fund One \\
\hline PF1STMF & MBL 1st Mutual Fund \\
\hline PHPMF1 & Phoenix Finance 1st Mutual Fund \\
\hline POPULAR1MF & PHP First Mutual Fund \\
\hline PRIME1ICBA & Popular Life First Mutual Fund \\
\hline RELIANCE1 & Prime Bank 1st ICB AMCL Mutual Fund \\
\hline SEBL1STMF & "Reliance One" the first scheme of Reliance Insurance Mutual Fund \\
\hline TRUSTB1MF & Southeast Bank 1st Mutual Fund \\
\hline & Trust Bank 1st Mutual Fund \\
\hline
\end{tabular}

